\title{
Psychological Aspects of Professional Suitability of Students at the Stage of Higher Education
}

\author{
A.N. Zakharova \\ Chuvash State University, \\ Cheboksary, Russia \\ E-mail: zaharova_an@mail.ru
}

\author{
N.A. Antonova \\ Chuvash State University, \\ Cheboksary, Russia
}

\author{
T.A. Lavina \\ Chuvash State University, \\ Cheboksary, Russia \\ D.V. Hartfelder \\ Chuvash State University, \\ Cheboksary, Russia
}

\author{
E.V. Yakovleva \\ Cherepovets State University, \\ Cherepovets
}

\begin{abstract}
The current socio-economic situation in the country and in the world places ever-higher demands on the professionalism of a person: a constant change in the nature and goals of work occurs, new professions arise, and the intensity and tension of work increases. The employee is required high professionalism, personal competitiveness, increased responsibility, the ability to work in conditions of economic and psychological uncertainty. The formation of professional suitability and competence of such a professional is impossible without reliance on the psychological qualities of a person. In this regard, the role of targeted career guidance work in the educational system has sharply increased, which should be based on a thorough knowledge of the entire system of the main factors that determine the future professional suitability of a specialist, including psychological ones. The article considers the psychological aspects of the professional suitability of students receiving higher education. On the basis of an empirical study, which was attended by 120 junior students receiving higher education in economics and finance, it is concluded that the professional inclinations and orientation, motivation for choosing a profession for the majority of students who took part in the study correspond to the choice of profession. At the same time, a certain part of students has been identified whose professional inclinations and motivation do not yet sufficiently correspond to the direction of study, and therefore this group requires in-depth psychological and pedagogical work in a higher educational institution. The article highlights the experience of the Russian regional university in building a career guidance system, shaping professional suitability and enhancing professional selfdetermination of student youth.
\end{abstract}

Keywords - the Russian system of higher education, higher education institution, professional suitability, future specialist, financial and economic specialties.

\section{INTRODUCTION}

The current socio-economic situation in the country and in the world places ever-higher demands on the professionalism of a person: a constant change in the nature and goals of work occurs, new professions arise, and the intensity and tension of work increases. The employee is required to have high professionalism, personal competitiveness, increased responsibility, and the ability to work in conditions of economic and psychological uncertainty.

The formation of professional suitability and competence of such a professional is impossible without reliance on the psychological qualities of a person. In this regard, the role of targeted career guidance work in the educational system has sharply increased, which should be based on a thorough knowledge of the entire system of the main factors that determine the future professional suitability of a specialist, including psychological ones. Recent studies show that about $40 \%$ of young people in our country choose a profession not well thought out and consciously, which complicates their subsequent effective training in professional competencies [1].

This makes scientific research in the field of psychology of professional suitability of students particularly relevant.

According to E.F. Zeer [2], professional formation is a process of development and self-development of a person, development and self-design of professionally oriented types of activity, determining one's place in the world of professions, realizing oneself in a profession and selfactualizing one's potential to achieve the heights of professionalism, the process of increasing the level and improving the structure of professional orientation, professional competence, socially and professionally important qualities and professionally significant psychophysiological properties through the resolution of conflicts between the current level of development, social situation and developing leading activity.

Professional formation of the personality is a progressive, phased process of personality transformation, accompanied by the formation and development of sustainable qualities and properties based on the acquisition of professional knowledge, 
According to the results of studies presented by skills through its self-actualization and self-realization in professional activities.

E.A. Klimov identifies five subject components of professional suitability: civil qualities of a person, employee's moral character, system of values, beliefs; attitudes to this type of work and organization (motives, interests, inclinations, emotional preferences); human capacity, physical and mental health; single and general abilities, talents, giftedness; skills, abilities, knowledge, professional qualifications and the general level of culture, literacy, or indicators of learning ability to special knowledge and skills. The importance of each component in the success of activities in different professions may vary [3].

Professional suitability by V.A. Bodrov [4] is determined by the totality of individual human characteristics that affect the success of the development of any labor activity and the effectiveness of its implementation. It reflects the real level of development of professionally significant qualities for a specific professional activity, which are formed and manifest at the stages of life and professional path. These include qualities that characterize the features of labor education and training, professional qualifications, the psychological structure of the person, health status and physiological functions, physical development, which are determined by the requirements of the profession.

The aim of this work is to study the characteristics of professional suitability of students receiving higher education, using the example of financial and economic specialties.

In accordance with the new educational standards in the field of training "Economics" in the Russian system of higher education, the field of professional activity of graduates is the economic, financial, marketing, industrial, economic and analytical services of organizations of various industries, spheres and forms of ownership, financial, credit and insurance institutions.

Among the specialists in economic profile are future entrepreneurs $[5,6,7]$, whom the Russian economy is in urgent need at present

At present, a paradoxical situation has arisen in the system of Russian higher education: the wide supply of educational services caused by demand by educational institutions of higher education in financial and economic specialties is accompanied, as a result, by an overabundance of such specialists in the labor market, despite the fact that in reality there is a rather sharply declared employer the need for employment of highly skilled workers of this profile [8].

According to the Federal State Statistics Service, the compliance of the work of employed graduates of 2015-2017. The graduation of a specialty in economics and management obtained in a higher education educational organization, according to a sample survey of labor in 2018, in $34 \%$ does not correspond to the specialty received. Employment in the field of economics and management is one of the highest, but at the same time, the unemployment rate among this sector with higher or secondary vocational education is also one of the highest [9].
L.Nabibullin, more than a third of employers are dissatisfied with the quality of domestic economic education, more than $60 \%$ of graduates cannot find jobs in their specialty, and three years after graduation, less than $20 \%$ of graduates work in areas related to with the profession [10]

There is a position according to which management education in Russia, as an intensively developing sector of the educational services market, offers various programs for training managers whose quality does not meet the needs of the society for training managers, and Western experience is often implemented at the level of external attributes without analyzing its essential characteristics, as a rule, "copying" activity patterns and ready-made knowledge that are theoretical in nature, divorced from real management practice [11].

The analysis of Russian studies on the study of professionally important qualities of specialists in financial and economic profile revealed the existence of two main approaches.

In one of them, the main emphasis is placed on the ability to competently perform work with abstract sign information, the ability to work with a variety of information presented in digital form for a long time.

In the studies that became classical in Russian psychology E.A. Klimov [3], it was revealed that among the psychological requirements of the profession of an accountant and an economist for a person, the main ones are the membership of this profession in the professional type "Man - Sign System". It is emphasized that the work of an economist is necessarily associated with calculations, the processing of large amounts of information, expressed in numbers. It is indicated that they should be able to deal well with information containing numbers, symbols, indicators, numerical ratios, tables, formulas, etc.

In the professiogram of the profession "economist" of the authoritative Russian author E.S. Romanova [12] as qualities that ensure the success of professional activities, stand out: analytical thinking; good development of concentration and shift of attention; high level of development of memory and mathematical (counting) abilities; ability to work in conditions of lack of time and information; the ability for a long time to engage in a monotonous type of activity, a tendency to work with documents, texts and numbers.

Another basic approach emphasizes the role of the specialist in the field of economics of the professionally important qualities associated with managing people.

According to Kolobkova N.N. [13] the formation of competitiveness of students in the economic profile is determined by the following indicators: positive professional motivation; striving for achievements; non-susceptibility to fatalism; information competence; communicative competence; technological competence; regulation of personal anxiety; switchable behavior; variability of action.

In the study of Dreizin I.V. [14] as a professionally important quality of students-future managers, creativity is 
Among the professionally important qualities of a manager, a structural "core" can be identified, including competencies that have the highest level of consistency for specialists in all areas of professional activity. This core includes core competencies such as: among personal competencies cognitive abilities, reflexivity, organizational abilities, responsibility, position activity, initiative (innovation), achievement motivation, communication properties, social pace (sociability), emotional-volitional and behavioral regulation; professionally oriented competencies include professional knowledge, skills, social skills and social control skills. Based on the analysis, the author concludes that these competencies are universal, i.e. their development determines the general level of professional suitability of a manager employed in any professional field. The author claims that the manager's activity in the overwhelming majority of cases requires high level of formation and expression of such competencies among specialists in the field of management of all types.

In the studies of Kicherova M.N., Efimova G.Z., Zyuban E.V. the fact is noted that, despite the fact that future economists are being prepared for various types of professional activities (settlement, economic, analytical, research, organizational and managerial, pedagogical), but according to the results of the study it was found that scientific activity and pedagogical work in the field of economics attract little students [20].

Thus, the analysis of the psychological characteristics of the professional suitability of future specialists in the field of financial and economic orientation showed that this problem has not yet been studied enough and requires special attention of researchers.

\section{MATERIALS AND METHODS}

In a study based on the FSBEI HE "The Chuvash State University named after I.N. Ulyanova", Cheboksary, received 120 students studying in economic specialties in the 1 st and 2nd year. Among then there are 86 girls and 34 young men. The age of the subjects was $17.78 \pm 0.45$.

The following psychodiagnostic techniques were used in the study:

1) Differential diagnostic questionnaire of E.A. Klimov,

2) Methodology for determining professional aptitudes by Yovayshi,

3) Methodology "Motives for choosing a profession" (Ovcharova R.V.) [21].

The basic statistical analysis was performed to calculate number of cases, percentage ratio, mean and standard deviation for discrete values.

To reveal valid interconnections between the indexes, Pearson's linear correlation r-coefficient was calculated with confidence level $\mathrm{p}<.05$. To assess the validity of the differences, analysis of variances (ANOVA) was conducted with confidence level $\mathrm{p}<.01$. that the structures of complexes of professionally important competencies of Russian managers in various fields have a rather high level of compositional and substantial similarity. psychologi doctor of pedagogical, sociological, sciences for 2002-2013, which reflects the of a study of professionally important qualities managers at various levels and areas of professional activity conducted by V. Katunova [19] made it possible to establish 
Exploratory cluster analysis (K-means clustering) was conducted to identify homogenous student groups based on results of psychodiagnostics. Discriminative analysis was conducted to confirm results of cluster analysis.

All the calculations were done with the help of Microsoft Office Excel 2010 and R 3.6.1 software.

\section{RESULTS AND DISCUSSIONS}

In accordance with the classification of E. Klimov, 78.33\% of future specialists in the field of economics have such a prevailing type of professional orientation as "person-person" (high rates for $43.33 \%$ and average rates for $25 \%$ of students). According to V.N. Kononova, A.G. Shmelev [22] such a choice generally corresponds to the socio-economic profile of training and is focused primarily on future work in the field of service and management.

The objects of professional activity of graduates who have mastered the undergraduate program in the field of preparation "Economics" are the behavior of business agents, their costs and results, functioning markets, financial and information flows, and production processes. Thus, graduates should be prepared for the following main types of professional activity: settlement and economic, accounting, settlement and financial, banking and insurance.

Students in the area under consideration in future professional activity need to be prepared to solve various kinds of professional tasks.

In the framework of settlement and economic activities the preparation of baseline data for the calculation of economic and socio-economic indicators characterizing the activities of business entities; development of economic sections of plans of enterprises of various patterns of ownership. Solving analytical tasks, a graduate should be able to search for information, collect and analyze data necessary for specific economic calculations. He must be able to build econometric models. The accounting activity of the graduate involves the documentation of business transactions and the accounting of property of the organization. Settlement and financial activity involves participation in the implementation of financial and economic planning. As part of banking, it is assumed that settlement transactions, credit operations, securities transactions, etc. insurance activities include the implementation of various sales technologies in insurance, support of insurance contracts, accounting and reporting of the insurance organization.

As the analysis of scientific sources has shown, specialists in the field of finance and economics have a professionally important focus in the field of "Man-the Sign System". In the study sample, it was expressed in $40.83 \%$, with high rates in only $30 \%$ of students. For a specialist in the field of "Man the Sign System", professionally important qualities are the ability to work with abstract sign information, to analyze, summarize, process information, developed abstract thinking, the ability to focus for a long time on abstract (sign) material, and to distribute attention. Common professions of this kind include an accountant and an economist.
The combination of high indicators in the field of "ManMan" and "Man-the Sign system" is characteristic of $12.5 \%$ of the sample, average $-65.83 \%$. Such respondents will be able to try their hand at such professions as a marketer, economist and analyst. In our opinion, focused work with this identified group in the University's Business Incubator as potential future entrepreneurs would be promising.

The second highest prevalence among students of economic specialties was the professional type "Man - the Artistic Image" - 56.66\% (high rates for $43.33 \%$ and average rates for $13.33 \%$ of students). In the last places where the severity of professional orientations "Man - Technique" (high and average rates in $25.83 \%$ of students) and "Man - Nature" (high and average rates in $20.83 \%$ of respondents). These trends are not professionally important for students studying in financial and economic specialties (Table 1).

TABLE I THE RESULTS OF THE METHODOLOGY "DIFFERENTIAL DIAGNOSTIC QUESTIONNAIRE"

\begin{tabular}{|c|c|c|c|c|c|c|}
\hline \multirow{2}{*}{$\begin{array}{c}\text { Professional } \\
\text { direction }\end{array}$} & \multicolumn{6}{|c|}{ The level of amount } \\
\cline { 2 - 7 } & $\begin{array}{c}|c| \\
\text { Abs., } \\
\text { man. }\end{array}$ & $\%$ & $\begin{array}{l}\text { Abs., } \\
\text { man. }\end{array}$ & $\%$ & $\begin{array}{c}\text { Abs., } \\
\text { man. }\end{array}$ & $\%$ \\
\hline «Man- Man» & 52 & 43.33 & 30 & 25.00 & 38 & 31.67 \\
\hline $\begin{array}{c}\text { «Man - the } \\
\text { Artistic Image» }\end{array}$ & 52 & 43.33 & 16 & 13.33 & 52 & 43.33 \\
\hline $\begin{array}{c}\text { «Man-the Sign } \\
\text { system» }\end{array}$ & 36 & 30.00 & 13 & 10.83 & 71 & 59.17 \\
\hline $\begin{array}{c}\text { «Man - } \\
\text { Technique» }\end{array}$ & 22 & 18.33 & 9 & 7.50 & 89 & 74.17 \\
\hline «Man - Nature» & 13 & 10.83 & 12 & 10.00 & 95 & 79.17 \\
\hline $\begin{array}{c}\text { «Man- Man» } \\
\text { «Man-the Sign } \\
\text { svstem» }\end{array}$ & 15 & 12.5 & 79 & 65.83 & 26 & 21.67 \\
\hline
\end{tabular}

Correlation analysis showed significant relationships between certain types of professional orientation:

- "Man-Man" and "Man-the Artistic image" ( $\mathrm{r}=0.29$; $\mathrm{p} \leq 0.01)$;

- "Man-the Sign system" and "Man-the Artistic image" (r $=0.22 ; \mathrm{p} \leq 0.05)$.

Test results by the method of determining professional inclinations Yovayshi showed that the greatest value in the sample as a whole is "a tendency to plan economic activities" - 17.23 \pm 3.30 . These are professions in which work is aimed at working with calculations, planning, numbers and identifying quantitative ratios (accountant, economist); paperwork, analysis of texts and their transformation; etc. Those who choose these professions have perseverance, accuracy, sufficiently developed mathematical abilities, and are distinguished by a practical, concrete approach to problems. A negative correlation relationship between this professional tendency and the professional orientation "ManNature" $(r=-0.22 ; p \leq 0.05)$ and the professional inclination "tendency to moving types of activity" $(\mathrm{r}=-0.4 ; \mathrm{p} \leq 0,01)$.

In second place in terms of severity as a whole in the sample is "a tendency to work with people" $(16.98 \pm 2.80)$. For them in the future profession, the most suitable job is 
A positive correlation was revealed between "internal related to service, management, training. People who are successful in the professions of this group are distinguished by developed communicative qualities, the ability to find a common language with different people, understand their mood, intentions, influence and convince. The negative correlation relationships of this professional tendency and the following professional inclinations were revealed:

- "propensity to mental activities" $(\mathrm{r}=-0.25 ; \mathrm{p} \leq 0.01)$,

- "a tendency to work in production" $(r=-0.19 ; p \leq 0.01)$,

- "a tendency to aesthetic activities" $(\mathrm{r}=-0.2 ; \mathrm{p} \leq 0.01)$.

We give the remaining results in descending order. In the next place $(15.23 \pm 3.69)$, a tendency to mobile activities, is characterized by increased requirements for physical fitness of a person and associated with travel, expeditionary and search work. Further, "a tendency to aesthetic activities" (13.98 \pm 4.4) - the psychological qualities of these people can most clearly manifest themselves in creative professions associated with visual, musical, literary, artistic, acting and stage activities. "Propensity to mental work" $(13.40 \pm 3.01)$ - as a rule, those who choose this field of activity are characterized by rationality, independence and originality of judgments, analytical mindset and they are not inclined to implement practical activities. The lowest indicators for professional inclination are "a tendency to work in the workplace" (12.71 \pm 3.22).

TABLE II MOTIVES FOR CHOOSING A PROFESSION

\begin{tabular}{|c|c|c|c|c|c|c|c|}
\hline \multirow{3}{*}{$\begin{array}{l}\text { Motives for } \\
\text { choosing a } \\
\text { profession }\end{array}$} & \multicolumn{7}{|c|}{ The level of amount } \\
\hline & \multicolumn{2}{|c|}{ high } & \multicolumn{2}{|c|}{ average } & \multicolumn{2}{|c|}{ low } & \multirow[b]{2}{*}{$\mathbf{M} \pm \sigma$} \\
\hline & $\begin{array}{l}\text { Abs., } \\
\text { man. }\end{array}$ & $\%$ & $\begin{array}{l}\text { Abs., } \\
\text { man. }\end{array}$ & $\%$ & $\begin{array}{l}\text { Abs., } \\
\text { man. }\end{array}$ & $\%$ & \\
\hline $\begin{array}{c}\text { Internal socially } \\
\text { significant motive }\end{array}$ & 66 & 55.00 & 45 & 37.50 & 9 & 7.50 & $16.74 \pm 12.80$ \\
\hline \begin{tabular}{|c|} 
Internal \\
individually \\
significant motive
\end{tabular} & 78 & 65.00 & 38 & 31.67 & 4 & 3.33 & $16.23 \pm 3.63$ \\
\hline $\begin{array}{c}\text { External positive } \\
\text { motives }\end{array}$ & 35 & 29.17 & 75 & 62.50 & 10 & 8.33 & $13.78 \pm 3.51$ \\
\hline \begin{tabular}{|c|}
$\begin{array}{c}\text { External negative } \\
\text { motives }\end{array}$ \\
\end{tabular} & 9 & 7.50 & 95 & 79.17 & 16 & 13.33 & $11.83 \pm 2.97$ \\
\hline
\end{tabular}

The results of the analysis of the main types of motivation when choosing a profession in the field of economics and finance were characterized by a predominance of internal individual-significant and internal socially significant motives. In terms of importance, when choosing a profession for students who took part in the study, the leading ones are such motives as internal socially significant ones $(16.74 \pm 12.80$, high level at 55\%, average at $37.50 \%$ ) and internal individually significant $(16.23 \pm 3.63$, high at $65 \%$, average at $31.67 \%)$

Internal motives for choosing a profession arise from the needs of a person and make it possible to work with greater labor productivity, without external pressure, experiencing high job satisfaction. For individuals with high internal motives, its personal and social significance, the creative nature of work, the possibility of leadership, interpersonal communications in a team, etc. may come to the fore. individually significant motives" and the professional type "Man-the Sign system" $((\mathrm{r}=0.18 ; \mathrm{p} \leq 0.05)$, that is, individuals with the psychological qualities necessary to work in the fields of economics and finance were guided by the significance of the chosen profession for the person himself, they assume that the profession corresponds to its abilities, the level of its development.

The next motivation for representation among students who took part in the study is "external positive motivies" $(13.78 \pm 3.51$, high level at $29.17 \%$, and average at $62.50 \%)$. This type of motivation is associated with ideas about the future profession as providing high wages and material incentives, career building and promotion opportunities, and high esteem of the prestige of the future profession. This type of motivation for choosing a profession revealed several positive significant correlation relationships:

- "external positive motivation" and "inclination to work with people" $(\mathrm{r}=0.26 ; \mathrm{p} \leq 0.01)$,

- "external positive motivation" and "a tendency to plan economic activities" ( $\mathrm{r}=0.18 ; \mathrm{p} \leq 0.05)$,

And the negative correlation relationship is "external positive motivation" and "inclination to mental types of work" $(\mathrm{r}=-0.20 ; \mathrm{p} \leq 0.05)$.

Negative external motives of choice in the last place among the possible motives presented $(11.83 \pm 2.97)$ and at a high level were manifested only in $7.5 \%$ of respondents (at an average level of $79.17 \%$ ). Negative external motives include influences on the person through pressure, criticism, any sanctions of a negative nature, as applied to applicants - future students. External negative motives may be manifested in the fact that applicants choose a future profession, based either on the opinion of their family alone, or the admission is due to the fact that this choice of profession has become, by virtue of any external circumstances, the only possible one for them. It is important here that the choice of profession did not become, albeit with time, an internal choice for a person, but is still perceived as imposed from the outside. This type of motivation is inherent only to female students (girls) $(\mathrm{r}=0.34$; $\mathrm{p} \leq 0.01)$ and has correlation relationships with the professional type "Man- Man - the Artistic Image" $(r=0.22 ; p \leq 0.05)$ and is not peculiar to persons with a professional inclination "a tendency to mental activities" $(\mathrm{r}=-0.25 ; \mathrm{p} \leq 0.01)$.

According to the results of the study, a group of students was identified who could suggest certain difficulties in future training in mastering the disciplines of the professional cycle and mastering professional competencies. $59.17 \%$ of students have low indicators of the type of professional orientation "Man - the Sign System", 31.67\% of students have a professional orientation "Man - Man". The combination of low indicators on each of these scales in $21.67 \%$ of those participating in the study.

Potential learning difficulties may also be associated with insufficient motivation for studying in a chosen specialty in the field of economics and finance. In the structure of motivation for entering a university, there are external motives, including negative external motivation. 
The agglomerative hierarchical cluster analysis of DDQ scales revealed three subsamples. Discriminative analysis aimed at stratification verification was also performed and it has confirmed the classification for $98.3 \%$ of the cases.

The first subsample $(n=41)$ is characterized by moderate high averaged values of all DDQ scales except "HumanNature interaction" scale with zero values. Statistically significant negative linear correlation of economic planned activities and movability activities scales of Jovaiša questionnaire was found $(\mathrm{r}=-0,5333 ; \mathrm{p}=0,0000)$.

The second subsample $(n=26)$ is characterized by very low averaged values of "Human-Nature interaction" scale (-8), moderate low values of "Human-Sign system interaction" \& "Human-Artistic imagery interaction" scales (-5 for both scales), below average value of "Human-Technical devices interaction" scale (-3) and zero values of "Human-Human interaction" scale. For the economic planned activities scale, statistically significant linear correlation was found with DDQ "Human-Human interaction" scale ( $\mathrm{r}=0,3907$; $\mathrm{p}=0,0486)$, as well as negative correlation with cognitive activities of Jovaiša questionnaire $(r=-0.4026 ; \mathrm{p}=0.0415)$.

The third subsample $(n=52)$ is characterized by high averaged values of "Human-Technical devices interaction" \& "Human-Artistic imagery interaction" scales $(9$ and 8 respectively), moderate high values of "Human-Human interaction" scale (6), above average values of "Human-Nature interaction" scale (2) and zero values of "Human-Sign system interaction" scale. Statistically significant linear correlations of Jovaiša questionnaire economic planned activities scale were found with "Human-Nature interaction" scale ( $\mathrm{r}=-$ $0.3520 ; \mathrm{p}=0.0103)$, social interaction activities scale $(\mathrm{r}=-$ $0.2943 ; \mathrm{p}=0.0341)$, movability activities scale $(\mathrm{r}=-0.3382$; $\mathrm{p}=0.0143$ ) and external positive motives scale of Ovcharova questionnaire $(\mathrm{r}=0.3207 ; \mathrm{p}=0.0200)$.

The results of ANOVA revealed not only statistically significant differences of DDQ scales but also cognitive $(\mathrm{F}=5,9351 ; \mathrm{p}=0,0035)$, production work $(\mathrm{F}=9,9784 ; \mathrm{p}=0,0001)$ and aesthetical activities scales $(\mathrm{F}=10,4054 ; \mathrm{p}=0,0001)$ of Jovaiša questionnaire as well.

The analysis of students' professional orientation and motivation revealed those students who need in-depth career guidance work on the formation of professional suitability and professional orientation in a higher educational institution. In addition, we concluded that a more thorough selection and professional orientation of university applicant is necessary.

Thus, in order to better prepare graduates for future professional activities, it is necessary to carry out work on the formation of professional suitability and professional orientation both at the stage of the pre-university period and in the process of studying at a university.

At the stage of study at a university, career guidance in a higher educational institution is implemented through the educational process (the role of production practices, the discipline "Introduction to the profession" is high, the organization of excursions and internships at specialized enterprises and organizations, the opening of various kinds of business incubators, the application of quasi-professional methods training). A specially organized research activity, including student design bureaus, has great career guidance potential. All this contributes to the provision of psychological, pedagogical and informational support for students in their choice of the direction of their future professional activity or further training (master's program, postgraduate study), as well as in social and professional selfdetermination.

At the stage of work with applicants, it is very important to help students and graduates of secondary specialized educational institutions to decide on the choice of profession. For this, vocational guidance diagnostics are carried out, open university days are organized at the university, tours of the university are organized, profile clubs are organized, Olympiads for schoolchildren, university Saturdays, vacation schools and others are organized [23]. In order to get acquainted with future professional activities, excursions are organized for children and their teachers.

At the FSBEI HE “ Chuvash State University named after I.N. Ulyanov" over the past few years, many projects have been implemented that are realizing this direction: Olympiads and competitions of research projects for schoolchildren, lectures by leading scientists of the university for schoolchildren, the creation of scientific associations for schoolchildren at the university, theme schools during the holidays for students.

The university successfully implements such a format of additional education for children as seasonal vacation schools conducted during the schoolchildren's vacations (summer, spring, winter, autumn), as one of the forms of the created university system for vocational guidance and an element for identifying and tracking intellectually and creatively gifted children.

One of the directions of the university's career guidance is the "University for Children" project, in which teachers and students of various specialties go to schools and conduct master classes with schoolchildren, introducing them to different areas of training at the university, and potential areas of future professional activity.

The project "University Saturdays" is being implemented, when leading university teachers give open lectures for high school students covering modern trends and areas of science.

One of the ongoing activities combines career counseling activities in the framework of the continuing education program with a program of psychological support for these activities in the form of computer psychological diagnostics and conducting educational game training for early career guidance "I and my future profession", aimed at creating a common idea of the professional inclinations and preferences of the participants.

Experience of the Chuvash State University named after I.N. Ulyanov also shows the relevance and effectiveness of organizing career guidance events for networking of a multidisciplinary university with educational organizations and enterprises of the region. In the conditions of a scientific and educational cluster uniting general educational institutions, institutions of higher education and scientific and 
production associations, the professionalization space for schoolchildren is becoming wider, it is possible to better ensure continuity between general and higher education, and to make training for school graduates more effective in mastering higher education programs.

An important element of career guidance work with schoolchildren, in our opinion, is the construction at the university of a holistic system of psychological and pedagogical support for gifted children of research activities in the interaction "school - higher education institution". Such work is aimed both at enhancing the scientific, intellectual and creative potential of students' personalities, and at early career guidance of schoolchildren. The university has scientific associations for pupils and students, as well as student design bureaus. In scientific circles for schoolchildren at the university, under the guidance of university teachers, children get acquainted with the basics of psychological and medical knowledge, laboratories of solar energy and high technology, radio transmitting and receiving devices, television, circuitry, a forensic laboratory, etc. Scientific sections are held at the university for student scientific conferences and contests specifically for schoolchildren, where they can present their first scientific research [24].

The university also has a system of psychological and pedagogical support for applicants, which includes the diagnosis of the individual personality traits of the applicant, the selection of the direction and profile of training, the design of the basic elements of a career in the intended professional activity.

Thus, the systematic approach implemented by the structural units of the university will ensure a high quality of career guidance work expands the available formats for such work, helps to make the right choice of a profession that corresponds to its psychological characteristics, suitable for a person and in demand in society.

\section{CONCLUSIONS}

Analysis of studies on the psychological characteristics of the professional suitability of future specialists in the field of finance and economics showed the existence of several approaches. In one of them, the main emphasis is placed on the ability to work with iconic, digital information; other, most professionally important scientists see developed communicative qualities aimed at managing and managing people.

An empirical study, which was attended by 120 students of a regional Russian higher education institution who are studying in junior courses in the specialties in the field of economics and finance, allowed us to conclude that the prevailing type of professional orientation "person - person" was identified among future specialists ( high and average rates in $78.33 \%$ of students); professional type "Man - Artistic Image" (56.66\% of respondents have high and average rates); "Man - the Sign system" (40.83\% of students have high and average rates). Of all types of professional inclinations according to the method of L.A. Jovayshy most pronounced "a tendency to plan economic activities" and "a tendency to work with people." An analysis of the main types of motivation when choosing a profession showed that they were characterized by a predominance of internal socially significant and internal individual motives.

The professional orientation, interests and inclinations of the majority of students who took part in the study mainly correspond to their profession choice; they also have selfmotivation and attitudes towards future professional activities.

At the same time, a certain part of students has been identified whose professional inclinations and motivation do not yet adequately correspond to the direction of training, which can cause difficulties in future training in mastering the professional cycle disciplines and mastering professional competencies. In this connection, this group requires in-depth psychological and pedagogical work on the formation of professional suitability in a higher educational institution. This work in a higher educational institution is possible through the implementation in the educational process and research activities, participation in student scientific associations, aimed at providing psychological, pedagogical and informational support to students in their choice of the direction of their future professional activity or further training (master's program, graduate school ), as well as in social and professional self-determination.

The results of the study are used in the practice of educational work with students of these specialties in the conditions of a Russian regional university, they also found their application in creating a "professional profile" of the highlighted specialties and providing psychological assistance to school graduates and university graduates in selecting a future profession in accordance with their inclinations and preferences.

\section{References}

[1] A.S. Mutyrova, "The work of the university on the formation of professional self-determination of high school students and the professional orientation of students", Bulletin of the Buryat State University, vol.1, pp. 98-102, 2010.

[2] E.F. Zeer, Psychology of professions, M.: Academic Project, Ekaterinburg: Business Book, 2003, p. 336.

[3] E.A. Klimov, Psychology of professional self-determination, M.: Publishing Center "Academy", 2004, p. 291.

[4] V.A. Bodrov, Methodological and theoretical questions of studying the problem of professional suitability of the subject of labor, Professional suitability: subject-activity approach Ed. V.A. Bodrova, M.: Publishing department "Institute of Psychology RAS", 2004, p.11.

[5] T. I. Sanchez, S. M. Perez, "The impact of education on the entrepreneurial intention of students in the bachelor of economics", Revista de estudios empresariales-segunda epoca, vol. 1. pp. 22-40, 2019. DOI: $10.17561 /$ ree.v2019n1.2

[6] I.L. Pluzhnik, T.O. Ilnitskaya, F. Lucci, "Are entrepreneurs born or made? Effective academic models to foster entrepreneurial graduates", Obrazovanie i nauka-education and science, vol. 20, Issue 5, pp. 56-78, 2018. DOI: 10.17853/1994-5639-2018-5-56-78

[7] E. Zabelina, O. Deyneka, D. Tsiring, "Entrepreneurial attitudes in the structure of students' economic minds", International journal of entrepreneurial behavior \& research, t. 25, vol.8, pp. 1621-1633, 2019. DOI: 10.1108/IJEBR-04-2018-0224

[8] O.V. Glukhova, "Features of professional self-determination of youth in the modern situation (for example, studies of students receiving education in financial and economic specialties)", Bulletin of YuUSU, Series "Psychology", vol.8, № 4, pp. 113-120, 2015. DOI: 10.14529 / psy150414 
[18] I.V. Volkov, The development of personal potentials of managers in the educational space of higher education, Abstract of diss. ... cand. psychol. sciences. N. Novgorod, 2012, 25 p. es/labor_force/\# (accessed 12.24.2019).

[10] L.G. Nabibullin, The socio-professional system of forming values among pupils and students as a means of their self-determination and becoming modern professionals. Professional groups: dynamics and transformation Ed. V.A. Mansurova. - M.: Publishing House of the Institute of Sociology of the Russian Academy of Sciences, 2009. p.210.

[11] L.B. Bakhtigulova, "Innovative and entrepreneurial competence of future managers as readiness and ability to work effectively in the new economic conditions", Scientific Dialogue, vol.11, pp. 488-494, 2017.

[12] E.S. Romanova, 99 popular professions. Psychological analysis and professiograms. SPb: Peter, 2008, p. 430

[13] N.N. Kolobkova, Formation of competitiveness of students of an economic profile, Abstract of diss. ... cand. ped sciences, Voronezh, 2004, $24 \mathrm{p}$.

[14] I.V. Dreizin, "Features of creativity and the level of its development among student managers", Siberian Psychological Journal, vol.38, pp.48-50, 2010.

[15] S.V. Shchedrotkina, "Theoretical foundations of the formation of professional competence of future specialists in economics at the university", Political Internet electronic scientific journal of the Kuban State Agrarian University, vol.116, pp. 319-337, 2016.

[16] O.I. Dorogina, "Professionally significant psychophysiological qualities of future managers", Education and Science, vol.6-2, pp. 81-89, 2009.

[17] E.P. Burnasheva, S.A. Parfenova, "Methodology for assessing the alignment of innovative and entrepreneurial competence of future specialists in the field of management". Problems of modern teacher education. vol. 61-4. pp. 42-45, 2018.

19] V.V. Katunova, "The specificity of professional and personal competencies of managers as the basis of their competitiveness", Modern Competition, vol.10 (5 (59)), pp.54-74, 2016.

[20] M.N. Kicherova, G.Z. Efimova, E.V. Zyuban, "Features of the process of primary professional socialization of students of economic specialties of institutions of higher professional education", Bulletin of Eurasian Science, vol. (5 (24)), p.98, 2014.

[21] V.N. Kononova, A.G. Shmelev, "DDO and the "Career Guidance": the continuity of domestic career guidance techniques", Bulletin of Moscow University. Series 14. Psychology, vol. 2, pp. 63-74, 2010.

[22] R.V. Ovcharova, Reference book of a school psychologist, M.: Education, 1996, pp.281-282.

[23] E. Zvereva, T. Lavina, O. Fedorenko, V. Chupina, I. Matyushchenko, N. Topolskiy, "The Development of Information Educational Environment". Ural Symposium on Biomedical Engineering, Radioelectronics and Information Technology (USBEREIT). pp. 244247. 2019, April. [Ural Symposium on Biomedical Engineering, Radioelectronics and Information Technology (USBEREIT), p. 488, 2019]

[24] A.Yu. Alexandrov, A.N. Zakharova, T.V. Talanova, S.B. Kharitonova, G.S. Dulina, N.G. Gubanova, "Modern tendencies of psychological and pedagogical support of gifted children", The European Proceedings of Social \& Behavioural Sciences. vol. XLV. pp. 669-678. 2018, may. [IFTE 2018 - 4th International Forum on Teacher Education, p.993, 2018]. 